\title{
A Magyar Alvásdiagnosztikai és Terápiás Társaság módszertani ajánlása a közúti jármúvezetők egészségi alkalmasságának vizsgálatához az obstruktív alvási apnoe szindróma vonatkozásában
}

\author{
Szakács Zoltán dr. ${ }^{1}$ - Ádám Ágnes dr. ${ }^{2}$. \\ Annus János Kristóf dr. ${ }^{3}$ - Csatlós Dalma dr. ${ }^{2}$ - László Andrea dr. ${ }^{2}$ \\ Kalabay László dr. ${ }^{2}$ - Torzsa Péter $\mathrm{dr}^{2}$ \\ ${ }^{1}$ Magyar Honvédség Egészségügyi Központ, Budapest \\ ${ }^{2}$ Semmelweis Egyetem, Általános Orvostudományi Kar, Családorvosi Tanszék, Budapest \\ ${ }^{3}$ SomnoCenter, Szeged, Alvászavar Központ
}

Az obstruktív alvási apnoe a leggyakoribb alvás alatti légzészavar. Az össznépességben gyakorisága 2-4\%, és legfontosabb jellemzője a felső légutak alvás alatti ismétlődő, részleges vagy teljes elzáródása, amelyet oxigéndeszaturáció és hirtelen ébredés követ. A kezelésben nem részesülő betegek 4-6-szor valószínúbben okoznak közlekedési balesetet, mint egészséges társaik. Az obstruktív alvási apnoe szűrésének célja, hogy csökkentse és megelőzze az egyik legveszélyesebb alvászavarban szenvedő betegek által okozott közlekedési balesetek előfordulását. 2015. április 1-jétől hatályba lépett a 13/1992. NM rendelet módosítása, amely a közúti jármúvezetők egészségi alkalmasságának vizsgálata során az obstruktív alvási apnoe szűrését is elrendeli. A Magyar Alvásdiagnosztikai és Terápiás Társaság a jogszabálynak megfelelő, a hazai viszonyokhoz illesztett módszertant dolgozott ki, amelynek segítségével a háziorvosok és a foglalkozás-egészségügyi szakorvosok könnyebben kiszűrhetik az obstruktív alvási apnoéra gyanús pácienseket, majd a betegség az alvásdiagnosztikai egységekben diagnosztizálható és hatékony kezelés indítható. A kezelésben részesülő, megfelelő együttmúködésû gépjármúvezetook rendszeres gondozásuk és ellenőrzésük mellett megkaphatják jármúvezetői engedélyüket. Orv. Hetil., 2016, 157(23), 892-900.

Kulcsszavak: obstruktív alvási apnoe, kivizsgálási algoritmus, gépjármű-vezetői alkalmassági vizsgálat

\section{Hungarian Society for Sleep Medicine guideline for detecting drivers with obstructive sleep apnea syndrome}

\footnotetext{
Obstructive sleep apnea is the most frequent sleep-disordered breathing. The prevalence of sleep apnea in the general population is $2-4 \%$ and the main characteristics of the disease are the intermittent cessation or substantial reduction of airflow during sleep, which is caused by complete, or near complete upper airway obstruction. Decreased airflow is followed by oxygen desaturation and intermittent arousals. Untreated patients are 4-6 times more likely to cause traffic accidents than their healthy counterparts. The aims of the obstructive sleep apnea screening are to prevent and reduce the incidence of serious car accidents, which are often caused by one of the most dangerous sleep disorders. Since April 1, 2015 a modification of the 13/1992 regulation has been in force in Hungary which orders screening of obstructive sleep apnea during medical checkup of drivers. The Hungarian Society for Sleep Medicine made a guideline according to the regulation which was adapted to national circumstances and family doctors, occupational health specialists can more easily screen obstructive sleep apnea in suspected patients. In sleep ambulances the disease can be diagnosed and effective treatment can be started. Patients receiving appropriate treatment and with appropriate compliance can get their driving licence under regular care and control.
} 
Keywords: obstructive sleep apnea, investigation algorythm, medical checkup for driving licence

Szakács, Z., Ádám, Á., Annus, J. K., Csatlós, D., László, A., Kalabay, L. Torzsa, P. [Hungarian Society for Sleep Medicine guideline for detecting drivers with obstructive sleep apnea syndrome]. Orv. Hetil., 2016, 157(23), 892-900.

(Beérkezett: 2016. március 1.; elfogadva: 2016. április 17.)

\section{Rövidítések}

$\mathrm{AHI}=$ apnoe-hypopnoe index $; \mathrm{BPAP}=($ bilevel positive airway pressure) kétszintű pozitív nyomású légzéstámogatás; $\mathrm{CA}=$ centrális apnoe; CAHS = centrális apnoe-hypopnoe szindróma; $\mathrm{CPAP}=($ continuous positive airway pressure $)$ folyamatos pozitív nyomású légzéstámogatás; EDS = (excessive daytime sleepiness) túlzott nappali aluszékonyság; ESS = (Epworth Sleepiness Scale) Epworth aluszékonysági skála; $\mathrm{OH}=$ obstruktív hypopnoe; OSAS = obstruktív alvási apnoe szindróma; SHVS = alvásfüggő alveoláris hipoventiláció szindróma

\section{Jogszabályi háttér}

2015. április 1-jétôl hatályba lépett a 13/1992. NM rendelet módosítása, amely a közúti jármúvezetők egészségi alkalmasságának vizsgálata során az obstruktív alvási apnoe szindrómában (obstructive sleep apnea syndrome OSAS) szenvedő betegek szûrését is elrendeli, mivel a fel nem ismert és kezeletlen kórképben érintettek komoly közlekedésbiztonsági kockázatot jelentenek mind önmaguk, mind valamennyi, közlekedésben résztvevő számára. A módosítást az egységes európai vezetői engedélyekről szóló 2006/126/EK irányelv honosítása indokolta.

A Magyar Alvásdiagnosztikai és Terápiás Társaság az Európai Bizottság által létrehozott Alvási Apnoe Munkacsoport 2013-as szakmai iránymutatásával összhangban [1] olyan, a hazai viszonyok között megvalósítható szưrési módszert ajánl, amellyel az OSAS-ban szenvedő, a közlekedésbiztonságra kockázatot jelentő gépjárművezetők nagy biztonsággal azonosíthatók a házi- és foglalkozás-egészségügyi orvosi gyakorlatban. Fontos szempont továbbá, hogy a módszertani ajánlás követésével a hatékony terápiát igénybe vevő és együttmúködő betegek számára a gépjármúvezetéshez szükséges egészségi állapot ismételten elérhető, majd fenntartható lesz.

Az alvászavarok diagnosztikájával és kezelésével azok a szakorvosok foglalkozhatnak, akik a 23/2012. (IX. 14.) EMMI rendelet szerint „az alvásmedicina szakértője” (szomnológus) licencvizsgával rendelkeznek. A jelen módszertani ajánlásban a szakorvos megnevezés ilyen licenccel rendelkező neurológus, tüdőgyógyász, belgyógyász, fül-orr-gégész vagy pszichiáter szakorvosra utal. Az alvásdiagnosztika és az alvásdiagnosztikai központok múködését a 60/2003. (X. 20.) ESZCSM rendelet a 0905 Alvásmedicina szakmakód alatt szabályozza.

\section{Az obstruktív alvási apnoe definíciója}

Az obstruktív alvási apnoe szindróma a felnőtt lakosság körülbelül 2-4\%-át [2], súlyos formája a felnőtt lakosság több mint 1\%-át érintheti. A prevalenciaadatok jelentős szórást mutatnak. Ennek elsősorban az az oka, hogy a különböző epidemiológiai vizsgálatokban az OSAS meghatározására más $\mathrm{AHI}$ - és $\mathrm{SaO}_{2}$-értékeket vagy csupán tünetleírást alkalmaztak (horkolás, légzésszünetek alvás alatt stb.). Jelentős nehézséget jelent az egyes eredmények összehasonlításában a hypopnoe és a RERA eltérő értékelése is. Az 1982 óta végzett vizsgálatok adatai alapján elmondható, hogy az OSAS kor- és nemfüggő prevalenciát mutat. Gyakrabban fordul elő a férfiakban és idősebb korban. Amennyiben az AHI >5 értékét alkalmazták, az OSAS gyakorisága férfiaknál 24\%, nőknél $9 \%$ volt. Ezeknél a populációknál az AHI értékét 15-re emelve a gyakoriság 9\%-ra, illetve 4\%-ra csökkent.

Utóbbi AHI-érték mellett a napközbeni közepes súlyosságú aluszékonyságot is bevéve, a gyakoriság 4\%, illetve 2\%-nak bizonyult. Epidemiológiai vizsgálatok - nem evidence-based szintú - eredményei arra mutatnak, hogy egyes etnikai minoritásokban (afroamerikaiak, romák) a prevalencia magasabb.

$\mathrm{Az}$ életkortól függő, a felső légutak nagyobb kollapszuskészségéhez vezető anatómiai változások részben magyarázhatják az OSAS prevalenciájának időskori növekedését [3]. Mások viszont azt találták, hogy a légzészavarindex (respiratory disturbance index - RDI) csak a BMI változásával áll összefüggésben és független az életkortól [4]. A Sleep-Heart-Health Study eredményei szerint a férfi nem és a BMI hatása az OSAS kialakulására az életkor növekedésével egyre kisebb, és az OSAS prevalenciája 65 éves kor fölött platófázisba kerül (stabilizálódik) [5]. Az életkor előrehaladásával a nappali tünetek viszont ritkábbá válhatnak.

\section{Centrális apnoe-hypopnoe szindróma (CAHS)}

\section{Általános jellemzők, patofiziológia}

Az idiopathiás centrális apnoe szindrómát repetitív, deszaturációval és ébredéssel járó apnoék/hypopnoék jellemzik, amelyeket nem kíséri a garat beszúkülése vagy elzáródása. A CA számos betegségben előfordulhat: 
Megjelenhet alveoláris hipoventiláció hypercapniás, hypocapniás és normocapniás formájában. A hypercapniás CA gyakran jár együtt alveoláris hipoventilácós szindrómával, így annak egyik jellemzőjeként is értelmezhető.

A normo- és hypocapniás formák jellemzők az idiopathiás centrális apnoéra, a Cheyene-Stokes-légzésre és a hegyibetegségre. A Cheyene-Stokes-légzés esetében normo- és hypocapniás CA-k jelennek meg. Az idiopathiás CA ritka. Csecsemőkorban a normális alváskép része egy-egy CA.

A jelenség lényege: ébrenlét-alvás fázis változásakor a légzőközpont afferens és efferens szárának koordinációs hibája és a fentieket kompenzáló mechanizmusok zavara. Elalvás során az NREM2-fázisban hirtelen csökken a $\mathrm{PaCO}_{2}$-re bekövetkező légzési stimulus (neural motor output), és az éber állapotban fiziológiás felső határnak számító $\mathrm{PaCO}_{2}$-érték ( $45 \mathrm{Hgmm}$ ) ebben a fázisban már olyan kevés lehet, hogy az úgynevezett apnoeküszöb alá esik.

$\mathrm{Az}$ apnoe alatt a $\mathrm{pCO}_{2}$-szint növekszik, a ventilációs drive beindul, ehhez adódik a hypoxia is, és ébredés következik be nemritkán hiperventilációval. $\mathrm{A} \mathrm{PaCO}_{2}$ ismét csökken, a gyors visszaalvás ismét apnoéhoz vezethet. NREM2- és REM-fázis, valamint REM és ébrenlét között hasonló mechanizmus áll fenn.

A centrális apnoék gyakran nem önállóan, hanem obstruktív apnoékkal és kevert apnoékkal vegyesen jelennek meg. Ebben az esetben akkor beszélünk centrális apnoe szindrómáról, ha a centrális apnoék aránya egy regisztrátumban meghaladja az 50\%-ot.

Az apnoék és hypopnoék társulhatnak alvásfüggő alveoláris hipoventilációs szindrómához (SHVS). Utóbbi tiszta formája azonban csak az apnoék/hypopnoék hiánya esetén mondható ki. Az OSAS és SHVS együttes jelenléte (úgynevezett overlap szindróma) esetén bizonyítandó, hogy az SHVS-re jellemző hypercapnia- és hypoxiaprofil az apnoéktól és hypopnoéktól függetlenül is jelen van.

Magyar epidemiológiai adat eddig kevés született. Egy háziorvosi praxis hypertoniás betegei körében 10 éven át végzett ABPM-szürés alapján az OSAS prevalenciája $5 \%$ volt [6]. A klinikai kép megjelenése komplex. A kórkép gyanúját veti fel a hangos, légzésszünetekkel járó horkolás, amelyhez túlzott nappali aluszékonyság társul, de gondolnunk kell erre a betegségre terápiarezisztens hypertonia, szívelégtelenség, szívritmuszavarok, diabetes, stroke, depresszió vagy kognitív diszfunkció, gastrooesophagealis refluxbetegség esetén is. Az aluszékonyság, az apnoéval gyakran együtt járó elhízás és az alvás töredezettsége, a szorongás és a depresszió azok a tényezők, amelyek leginkább befolyásolják az életminőség különböző dimenzióit, és jelentős életminőség-csökkenéshez vezetnek $[7,8]$.

Az OSAS fó jellemzője a felső légutak alvás alatti ismétlődő, részleges (hypopnoe) vagy teljes elzáródása (apnoe), amelynek következtében a beteg egyre erőteljesebb légzőmozgásokat végez. Ezt a szúkületet, elzáró- dást a légzés központi idegrendszeri szabályozásának gyengesége, valamint a felső légút strukturális vagy funkcionális szúküuletei okozzák.

Apnoéról beszélünk, ha a légzés alatt a légáramlás legalább 80\%-kal csökken vagy teljesen megszûnik, és ennek az epizódnak az időtartama meghaladja a 10 másodpercet. A hypopnoe a légutak részleges elzáródása alvás alatt, definíció szerint a légáramlás az alaplégzéshez képest legalább 30\%-kal csökken, amelyet az oxigénszaturáció legalább 4\%-os csökkenése kísér [9].

Tünetmentes betegnél az OSAS diagnosztikai kritériuma az alvás alatt óránként 15-öt meghaladó apnoehypopnoe index $(\mathrm{AHI})$, míg panaszt (például nappali álmosság, krónikus fáradtság és figyelmetlenség) vagy megzavart alvás (horkolás, nyugtalan alvás és alvás alatti légzésszünet) tüneteit említő betegnél $5 \mathrm{AHI} / \mathrm{h}$ felett beszélünk OSAS-ról [8].

A betegségre nem jellemző, hogy spontán módon gyógyulna vagy javulna, így azzal a betegnek sokszor élete végéig együtt kell élnie. Az OSAS gyakori kockázati tényezőit az 1. táblázatban foglaltuk össze.

1. táblázat |Az OSAS rizikótényezői

1. Obesitas, különösen a nyakon.

2. Férfi nem.

3. 40-65 éves életkor.

4. Craniofacialis abnormalitások (Prader-Willi-szindróma, Down-kór stb.), mandibularis/maxillaris hypoplasia, retrognathia.

5. Nazális obstrukció különböző formái.

6. A garat lágy részeinek és lymphoid szöveteinek hyperplasiája.

7. Macroglossia.

8. Teljes foghiány.

9. Endokrin eltérések: hypothyreosis, acromegalia.

10. Családi halmozódás

11. Nikotin-, alkoholabúzus.

Az évek múlásával a kezeletlen betegség mértéke progresszíven súlyosbodik és súlyos szövődmények, társbetegségek jelenhetnek meg (2. táblázat). A legeredményesebb kezelés, a légsínterápia (continuous positive airway pressure - CPAP) sem hoz gyógyulást, csupán tüneti kezelést nyújt. A betegséghez társuló szövődmények megjelenése előtt kiemelten fontos a kórkép időben történő felismerése.

\section{Az OSAS és a közúti jármúvezetés}

Az 1970-es években leírt OSAS és a gépjármúbalesetek közötti összefüggés az 1990-es évek végére vált nyilvánvalóvá [10]. Ismert tény, hogy a nappali aluszékonyság szoros összefüggésben áll a közlekedési balesetekkel. A kezeletlen OSAS-betegek 4-6-szor valószínúbben okoznak közlekedési balesetet, mint egészséges társaik 
2. táblázat | Obstruktív alvási apnoéhoz gyakran társuló szövődmények, társbetegségek

\begin{tabular}{|c|c|}
\hline Kardiológia & $\begin{array}{l}\text { Hypertonia, balkamra-hypertrophia, } \\
\text { angina pectoris, szívinfarktus, arrhythmia, } \\
\text { szívelégtelenség, cor pulmonale, perifériás } \\
\text { oedema, hirtelen halál }\end{array}$ \\
\hline Pulmonológia & $\begin{array}{l}\text { Légzési elégtelenség, fulladás, pulmonalis } \\
\text { hypertonia }\end{array}$ \\
\hline Endokrinológia & $\begin{array}{l}\text { Diabetes mellitus, inzulinrezisztencia, } \\
\text { metabolikus szindróma, acromegalia, } \\
\text { hypothyreosis }\end{array}$ \\
\hline Neurológia & $\begin{array}{l}\text { Stroke, epilepszia, memóriazavarok, } \\
\text { kognitív diszfunkció }\end{array}$ \\
\hline Gasztroenterológia & GERD \\
\hline Hematológia & Polycytaemia \\
\hline Pszichiátria & Depresszió, szorongás, szkizofrénia \\
\hline Urológia & Nocturia, impotencia \\
\hline Szülészet-nőgyógyászat & $\begin{array}{l}\text { Terhesség, menopausa, polycystás } \\
\text { ovarium }\end{array}$ \\
\hline Fül-orr-gégészet & $\begin{array}{l}\text { Torok- és orrmandula-megnagyobbodás, } \\
\text { elongált uvula, gátolt orrlégzés }\end{array}$ \\
\hline Szemészet & $\begin{array}{l}\text { Glaucoma, ischaemiás opticus } \\
\text { neuropathia }\end{array}$ \\
\hline Aneszteziológia & $\begin{array}{l}\text { Nehezített intubáció, posztoperatív } \\
\text { apnoék }\end{array}$ \\
\hline Fogászat & Retrognathia, micrognathia \\
\hline
\end{tabular}

[11-13]. A hivatásos soförök 59,6\%-a szenvedett valamilyen alvásfüggő légzészavarban és 15,8\%-uk obstruktív alvási apnoe szindrómában [14]. 1988-ban csupán az elalvásos balesetek, amelyek 30-35\%-a hátterében igazolható OSAS, 43-56 milliárd dollár teljes gazdasági kárt okoztak $[15,16]$. Arbus 110, 18-70 éves gépkocsivezető súlyos következményekkel járó elalvásos balesetét dolgozta fel, és 31\%-uknál igazolt OSAS-t a baleset hátterében [17]. Az OSAS kóros nappali fáradékonyságot és alváskésztetést okozva 5-8-szorosára növeli az elalvásos közlekedési és üzemi balesetek veszélyét.

A legtöbb gépjármúvezető az 1 . alkalmassági csoportba tartozik. A 2-es csoportba tartozók a kérelmezók kisebb csoportját alkotják, de ők sokkal több idôt töltenek a közlekedésben. Így arányaiban közel egyforma baleseti kockázatot jelent a két csoport, ezért a szúrést a vezetői engedélyt kérők teljes körében el kell végezni.

\section{Közúti jármúvezetők egészségi alkalmasságának vizsgálata}

Az l. alkalmassági csoportba kell sorolni azt a közúti jármúvezetőt, aki az „Al” kategóriába, „A2” kategóriába, „A" korlátozott kategóriába, „A” kategóriába, „Bl” kategóriába, „B” kategóriába, „BE” kategóriába tartozó jármúvet vezet vagy kíván vezetni.

A 2. alkalmassági csoportba (hivatásos jogosítvány) kell sorolni azt a közúti jármúvezetőt, aki „Cl”, „ClE”,
„C”, „CE”, „Dl”, „DlE”, „D”, „DE” kombinált vagy „TR” trolibusz kategóriába tartozó jármúvet vezet vagy kíván vezetni, vagy a közúti közlekedési szolgáltatás keretében közúti jármúvet, megkülönböztető jelzéssel ellátott közúti jármúvet vezet vagy kíván vezetni, valamint akit közúti jármúvezetói munkakörben foglalkoztatnak, függetlenül a vezetni kívánt jármú kategóriájától. Gyakoribb orvosi ellenőrzés szükséges a 2. alkalmassági csoport esetén, ezért rövidebb időtartamra adható meg az orvosi engedély (a 60. életév betöltéséig 5 évenként, 60 . életév felett 2 évenként).

\section{Javasolt diagnosztikai és terápiás folyamat az OSAS kiszürésére}

A kérelmező esetében a kórkép fennállásának lehetőségét első lépésben háziorvosának vagy a foglalkozásegészségügyi szakorvosának kell elbírálnia (alapszürés).

\section{Alapszürés}

Az elbíráláshoz javasolt módszer egy szürô kérdôin használata, amelyet a 2013-as brüsszeli OSAS-munkacsoport értekezletén az európai alvástársaságok delegált szakértői konszenzussal hoztak létre. A teszt eredményétől függően az egészségi alkalmasság az első fokon eljáró szervnél helyben megítélhető, illetve kiderül, hogy lesz-e szükség további múszeres vizsgálatra. OSAS gyanúja esetén a kérelmezőt alvásdiagnosztikai központba kell továbbirányítani, ahol az előszưrést múszeres szúrővizsgálat követi.

\section{Alvásdiagnosztikai vizsgálat}

A kérelmezőnek kiadott müszerrel az otthonában végzett szürốpizsgálat eredménye elkülöníti a nem vagy csak enyhe mértékben érintetteket azoktól, akiknél a betegség mérsékelt vagy súlyos formában jelentkezik.

A müszeres szürővizsgálattal felállított, nagy valószínúségú iránydiagnózist az alvásdiagnosztikai központban elvégzett poliszomnográfiás vizsgálat erősíti meg. A következő lépés a terápia megválasztása és beállítása. Egy rövid időn belül végzett ellenőrző vizsgálattal a terápia hatékonyságáról és a beteg együttmúködéséről is meggyőződik a központ szakorvosa, aki minden lépés során tájékoztatja a kérelmezôt és a vizsgálatot indikáló orvost a konszenzusban meghatározott lehetőségekról vagy korlátozásokról.

\section{Az OSAS szürésére alkalmazott segédlet használatának ismertetése, kiértékelése}

Az OSAS lehetőségének elbírálása során az első tíz kérdéssel rögzítésre kerül a páciens neme, életkora, testsúlya, testmagassága, történt-e korábban vezetés közbeni elalvás, volt-e aluszékonyság miatt súlyos (személyi sérü- 


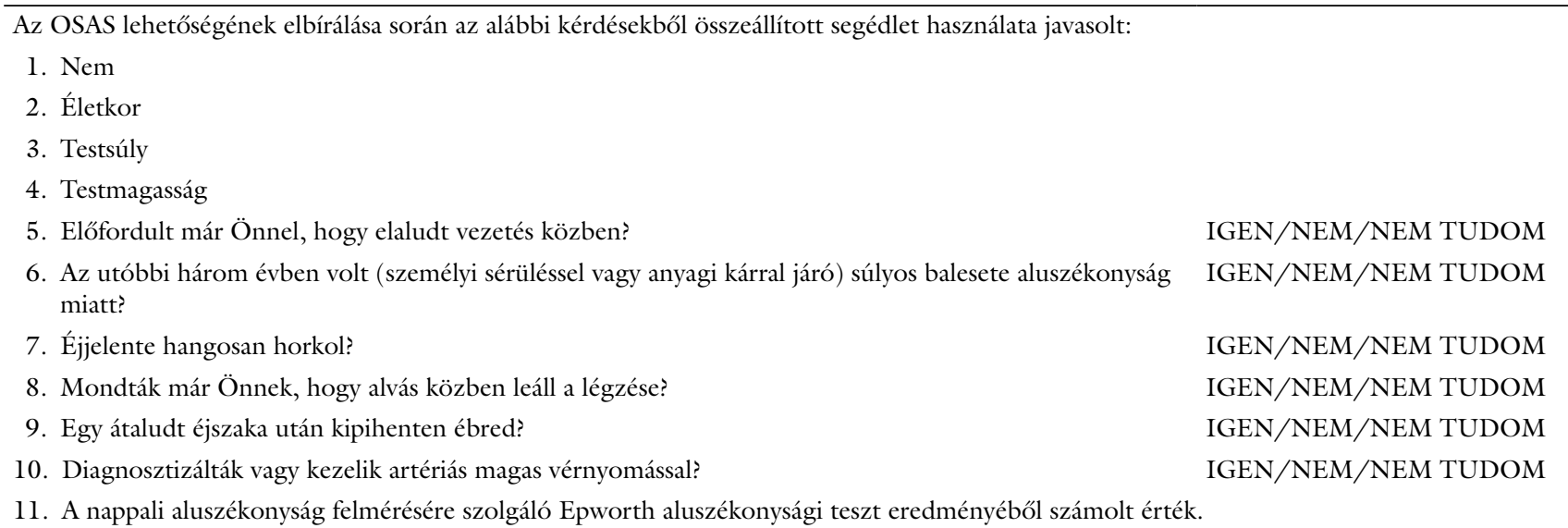

Értékelés:

Minden válaszhoz tartozik egy érték, amelyet az OSAS-sal való lehetséges összefüggés szerint súlyoznak.

1. kérdés: nő $=1$; férfi $=2$

2. kérdés: 30 év alatti életkor $=1 ; 31$ éves vagy magasabb életkor $=2$

$3-4$. kérdés: $30 \mathrm{~kg} / \mathrm{m}^{2}$ alatti $\mathrm{BMI}=1 ; 31-35 \mathrm{~kg} / \mathrm{m}^{2}=2 ; 36 \mathrm{~kg} / \mathrm{m}^{2}$ vagy magasabb $=3$

5. kérdés: pozitív válasz $=3$; negatív válasz $=0 ;$ nem tudja $=2$

6. kérdés: pozitív válasz $=4 ;$ negatív válasz $=0 ;$ nem tudja $=3$

7. kérdés: pozitív válasz $=2 ;$ negatív válasz $=0 ;$ nem tudja $=1$

8 . kérdés: pozitív válasz $=1 ;$ negatív válasz $=0 ;$ nem tudja $=0$

9. kérdés: pozitív válasz $=2 ;$ negatív válasz $=0 ;$ nem tudja $=1$

10. kérdés: pozitív válasz $=2 ;$ negatív válasz $=0 ;$ nem tudja $=1$

11. kérdés: A teszt egy 8 kérdésből álló kérdőív, kérdésenként négy lehetséges válasszal, amelyek értéke 0 és 3 között változhat, így a maximálisan elérhető 24 pont a legsúlyosabb nappali aluszékonyságot jelöli. Az egészséges alanyok átlagos ESS-pontszáma 10 alatti; a 11 -14 pontot enyhén rendellenes nappali aluszékonyságnak, míg a 15 pontot vagy annál magasabb értéket súlyos alszékonyságnak kell tekinteni.

Pontozás: ESS $0-10=0$;

ESS $11-14=2$;

ESS 15 vagy magasabb $=4$ pont.

\section{Összegzés:}

Ha a segédlet eredménye 10 pont vagy annál magasabb, a szúrés eredménye pozitív.

Abban az esetben, ha a szürés eredménye nem éri el a 10 pontot, de az ESS aluszékonysági teszt pontszáma nagyobb 14-nél, vagy a BMI érték nagyobb 35-nél; vagy az OSAS-sal gyakorta társuló következő kórképek: magas vérnyomás, szívritmuszavar, elszenvedett stroke vagy szívinfarktus, cukorbetegség valamelyike azonosítható a vizsgált személynél, egyedi mérlegelés alapján az eredmény szintén pozitívnak minősíthetö.

Ha a segédlet eredménye kevesebb, mint 10 pont, és a kiegészítő feltételek sem teljesülnek, a szürés eredménye negatív.

léssel vagy anyagi kárral járó) balesete az elmúlt 3 évben, éjjelente hangosan horkol-e, észrevették-e, hogy alvás közben leáll a légzése, mennyire ébred a páciens kipihenten, és diagnosztizáltak-e nála korábban hypertoniát vagy kezelték-e korábban emiatt. Minden válaszhoz tartozik egy érték, amelyet az OSAS-sal való lehetséges öszszefüggés szerint súlyoztak (3. táblázat).

A szürő kérdőív második része a nappali aluszékonyság felmérésére szolgáló önkitöltő Epworth aluszékonysági teszt (Epworth Sleepiness Scale - EES), amely 8 kérdésből álló kérdőív, kérdésenként négy lehetséges válasszal, amelyek értéke 0 és 3 között változhat, így a maximálisan elérhető 24 pont a legsúlyosabb nappali alu- székonyságot jelöli. A vizsgált személy az elmúlt egy hónap vonatkozásában pontozza annak valószínúségét, hogy elalszik-e bizonyos helyzetekben. Az egészséges alanyok átlagos ESS-pontszáma 10 alatti; a 11-14 pontot enyhén rendellenes nappali aluszékonyságnak, míg a 15 pontot vagy annál magasabb értéket súlyos aluszékonyságnak kell tekinteni. ESS: 11-14 pont esetén a páciens 2 pontot kap, 15 pont felett 4 pontot, és ez a pontszám adódik hozzá a teszt első részében kapott értékhez [18].

Ha a két kérdőív összesített eredménye 10 pont vagy annál magasabb, a szürés eredménye pozitív. 
Abban az esetben, ha a szürés eredménye nem éri el a 10 pontot, de az ESS aluszékonysági teszt pontszáma nagyobb 14-nél vagy a testtömegindex (BMI) nagyobb $35 \mathrm{~kg} / \mathrm{m}^{2}$-nél, vagy az OSAS-sal gyakorta társuló kórképek - magas vérnyomás, szívritmuszavar, elszenvedett stroke vagy szívinfarktus, cukorbetegség - valamelyike azonosítható a vizsgált személynél, egyedi mérlegelés alapján az eredmény szintén pozitívnak minősíthető.

Ha a segédlet eredménye kevesebb, mint 10 pont és a kiegészítő feltételek sem teljesülnek, a szürés eredménye negatív.

A teszt végén a páciensnek írásban nyilatkoznia kell arról, hogy a közölt adatok megfelelnek a valóságnak.

\section{A gépjármú-vezetői alkalmasság elbírálása a különböző szakmai szinteken}

\section{Az elsö és másodfokon eljáró egészségi alkalmassági vizsgálatot végző szerv esetében alkalmazandó irányelvek}

1. A közúti jármúvezetők egészségi alkalmasságát első fokon vizsgáló szerv (háziorvos, foglalkozás-egészségügyi szakorvos) feladata az OSAS lehetőségének elbírálása a kérelmező esetében.

1.A - Azon kérelmezők esetében, akiknél alvásdiagnosztikai központban már korábban elvégzett szakorvosi vizsgálat OSAS-t állapított meg, a 4. pontban leírtak szerint kell eljárni.

1.B - Minden egyéb esetben a kérelmezóknél a segédlet használatával kell felmérni az OSAS fennállásának lehetőségét.

2. Azon kérelmezők esetében, akiket a segédletben negatívként határoztak meg a vezetői engedély megszerzésekor vagy megújításakor, az egészségi alkalmasság megállapítható az OSAS vonatkozásában.

3. Azon kérelmezők esetében, akiket a segédletben pozitívként határoztak meg a vezetői engedély megszerzésekor vagy megújításakor, az alábbiak szerint kell eljárni:

3.A - Olyan alvásdiagnosztikai központban kiállított szakorvosi vélemény megszerzése szükséges, amely kizárja vagy megerősíti a mérsékelt vagy súlyos OSAS jelenlétét (4. táblázat).

3.B - Az OSAS gyanítható fennállása esetén a diagnózis felállításáig, illetve a kezelés megkezdéséig javasolni kell a gépjármúvezetéstől való tartózkodást. A 13/1999. NM rendelet 5 . $\$$ (3) bekezdés alapján az ehhez szükséges időtartamra megállapítható az egészségi alkalmasság, ha a gépjármúvezető nem szenved súlyos nappali aluszékonyságban (ESS érték 15 alatti), és nyilatkozatban elismeri, hogy tudatában van az állapotával járó lehetséges közlekedésbiztonsági kockázatnak és tüneteitől függően tartózkodik a gépjárművezetéstől.
4. táblázat Az alvási apnoe betegség kezelését végző alvásdiagnosztikai központok

MH Egészségügyi Központ, Alvásdiagnosztikai és Terápiás Centrum

Cím: 1134 Budapest, Róbert Károly krt. 44. IV. épület, földszint Telefon: (06-1) 212-1846, (06-1) 457-0980

SomnoCenter Budapest Alvászavar Központ

Cím: 1012 Budapest, Márvány u. 17.

Telefon: (06-20) 500-7993

Semmelweis Egyetem, Pulmonológiai Klinika, Alvásmedicina Szakambulancia

Cím: 1021 Budapest, Diósárok út 1/C

Telefon: (06-20) 663-2556

Országos Korányi TBC és Pulmonológiai Intézet, Alvásdiagnosztikai Laboratórium

Cím: 1121 Budapest, Pihenő út 1.

Telefon: (06-1) 391-3200/3264 mellék

Debreceni Egyetem, Neurológiai Klinika, Alvásdiagnosztikai és Terápiás Központ

Cím: 4024 Debrecen, Móricz Zsigmond krt. 22. (Auguszta telep)

Telefon: (06-52) 255-454

Pécsi Tudományegyetem, Neurológiai Klinika, Alvásdiagnosztikai és Terápiás Központ

Cím: 7623 Pécs, Rét u. 2. I. emelet

Telefon: (06-72) 535-961

SomnoCenter Pécs Alvászavar Központ

Cím: 7627 Pécs, Vadász u. 6. fszt. 3.

Telefon: (06-30) 476-1400

Szent-Györgyi Albert Klinikai Központ, Dél-alföldi Regionális Alvásdiagnosztikai Centrum

Cím: 6725 Szeged, Kálvária Sgt. 57. „G” épület

Telefon: (06-62) 540-875

SomnoCenter Szeged Alvásdiagnosztikai és Terápiás Központ Cím: 6725 Szeged, Kálvária Sgt. 57. „G” épület

Telefon: (06-20) 368-8580

Markusovszky Kórház, Tüdőgyógyászati Osztály, Alváslaboratórium Cím: 9700 Szombathely, Markusovszky Lajos u. 3.

Telefon: (06-94) 515-607

Tüdőgyógyintézet Törökbálint, Alvásdiagnosztikai Laboratórium Cím: 2045 Törökbálint, Munkácsy M. u. 70.

Telefon: (06-30) 566-7579

4. Azon kérelmezők esetében, akiket OSAS-sal diagnosztizáltak, és vezetői engedélyt kívánnak szerezni vagy azt megújítani, az alábbiak szerint kell eljárni: 
4.A - A kérelmezőnél, akinél a szakorvosi vizsgálat kezelést igénylő OSAS-t állapított meg, de nem áll kezelés alatt, és hajlandóságot sem mutat a szükséges terápia igénybevételére, az egészségi alkalmasság nem mondható ki (nem alkalmas).

4.B - Az a kérelmező, akinél a szakorvosi vizsgálat kezelést igénylő OSAS-t állapított meg, és még nem áll kezelés alatt, vezetői engedélyt kaphat, abban az esetben, ha hajlandóságot mutat a terápia igénybevételére, nem tapasztal fokozott nappali aluszékonyságot $(\mathrm{ESS}<15)$, nem volt a közelmúltban aluszékonysághoz köthető gépjármúbalesete és a BMI-értéke $35 \mathrm{~kg} / \mathrm{m}^{2}$ alatti. Nyilatkozatban el kell ismernie, hogy tudatában van az állapotával járó lehetséges közlekedésbiztonsági kockázatnak és tüneteitől függően tartózkodik a gépjármúvezetéstől.

4.C - Az a kérelmező, akinél a szakorvosi vizsgálat kezelést igénylő OSAS-t állapított meg, és aki a szakmai ellátási protokoll szerinti hatékony kezelésben részesül, továbbá együttmúködése megfelelö, jármüvezetôi engedélyt kaphat. A kezelés szükségességét és az utasítások betartását a kezelőorvosnak ellenőriznie kell, az 1. alkalmassági csoportba tartozó gépjármúvezetők esetében háromévente, a 2. alkalmassági csoportba tartozók esetében pedig évente.

4.D - Az a kérelmező, akinél a szakorvosi vizsgálat kezelést igénylő OSAS-t állapított meg, és aki a terápiát állitása szerint betartja, de ezt friss szakorvosi lelettel nem tudja igazolni, megkaphatja vezetői engedélyét, de a kezelőorvosnak 3 hónapon belül be kell mutatnia a somnológus szakvéleményét. A gépjármúvezetőnek nyilatkoznia kell arról, hogy tudatában van az állapotával járó lehetséges közlekedésbiztonsági kockázatnak és tüneteitől függően tartózkodik a gépjármúvezetéstől.

\section{Az alvásdiagnosztikai központok szakorvosai által alkalmazandó irányelvek}

OSAS-sal diagnosztizált gépjármúvezető egészségi alkalmassága az alábbiak szerint állapítható meg:

1. Enyhe fokú OSAS-sal diagnosztizált (AHI: 5-15) gépjármúvezető esetében az egészségi alkalmasság megitélhetō kezelés nélkül, amennyiben a gépjárművezető nem tapasztal túlzott nappali aluszékonyságot (ESS <15); nem volt aluszékonysághoz köthető gépjármübalesete; nem szenved két vagy több hatóanyaggal kontrollálható magasvérnyomás-betegségben, BMIértéke pedig $35 \mathrm{~kg} / \mathrm{m}^{2}$ alatti.

2. Mérsékelt vagy súlyos fokú OSAS-sal diagnosztizált gépjárművezető számára az egészségi alkalmasság megfelelően alkalmazott és hatékony terápia mellett állapitható meg.
2.A - Pozitív nyomású légsínterápia (CPAP, BPAP bilevel positive airway pressure - kétszintú pozitív nyomású légzéstámogatás) esetén a kezelés minimálisan elfogadható mértéke a vizsgált időszak napjainak 70\%-ában legalább 4 óra/nap használat. A vizsgált időszak újonnan kezelés alá vont beteg esetében 2-4 hét, más esetben a szakorvosi kontrollvizsgálatok között eltelt idő.

2.B - Egyéb kezelések - mint szájprotézisek, mütéti beavatkozások, életmód-terápiák (testsúlycsökkentés), gyógyszeres kezelések - esetén az egészségi alkalmasság akkor állapítható meg, ha 15-nél kevesebb maradvány AHI-érték igazolható a kontroll-alvásvizsgálat során és nincs jelen fokozott nappali aluszékonyság $(\mathrm{ESS}<15)$. A kezelés további szükségességét és a kezelési utasítások betartását időről időre szakorvosnak kell ellenőriznie. A kontrollok esedékessége az 1. és a 2. csoportba sorolt gépjármúvezetők esetében három, illetve egy év, amelyet a vezetői engedélyt kiállító orvosnak ellenőriznie kell.

3. Az OSAS-sal diagnosztizált gépjármûvezetőt haladéktalanul egészségileg alkalmatlannak kell minösiteni, ha az alábbi feltételek bármelyike teljesül:

- A gépjármúvezető vezetés közben fokozott nappali aluszékonyságot tapasztal (Epworth aluszékonysági skála értéke $\geq 15$ ).

- A gépjármúvezető aluszékonysága miatt közlekedési balesetet okozott.

- OSAS-sal diagnosztizált gépjárművezető, aki a kezelési utasításokat nem tartja be és a szakorvosi ellenőrzésen nem jelenik meg.

A közleményünkben ismertetett kivizsgálási algoritmus az 1 . ábrán látható.

\section{Következtetések}

Az OSAS szürésének célja, hogy csökkentse és megelőzze az egyik legveszélyesebb alvászavarban szenvedő betegek által okozott, gyakran tragikus kimenetelú közlekedési balesetek előfordulását. A jelen közleményben a Magyar Alvásdiagnosztikai és Terápiás Társaság a 13/1992. NM rendelet 2015. április 1 -jétől hatályba lépett módosításának és az EU Bizottság OSAS-munkacsoportja által 2013-ban létrehozott iránymutatásának megfelelóen azt a hazai viszonyokhoz illesztett módszertant ajánlja, amellyel ez a cél a leghatékonyabban és következetesen megvalósítható. Bízunk abban, hogy ez nemcsak a közlekedés biztonságát szolgálja majd, hanem lehetőséget teremt a betegség korai felismerésére is, még azelőtt, hogy a sokszor irreverzibilis szövődmények megjelennének (hypertonia, stroke, koszorúér-betegség, cukorbetegség, depresszió, szorongás, szellemi teljesítmény hanyatlása, demencia, személyiségváltozás). Ebben a folyamatban a háziorvosoknak és a foglalkozásegészségügyi szakorvosoknak kiemelt jelentőségü szerepe van, míg az OSAS végleges diagnózisa és a meg- 


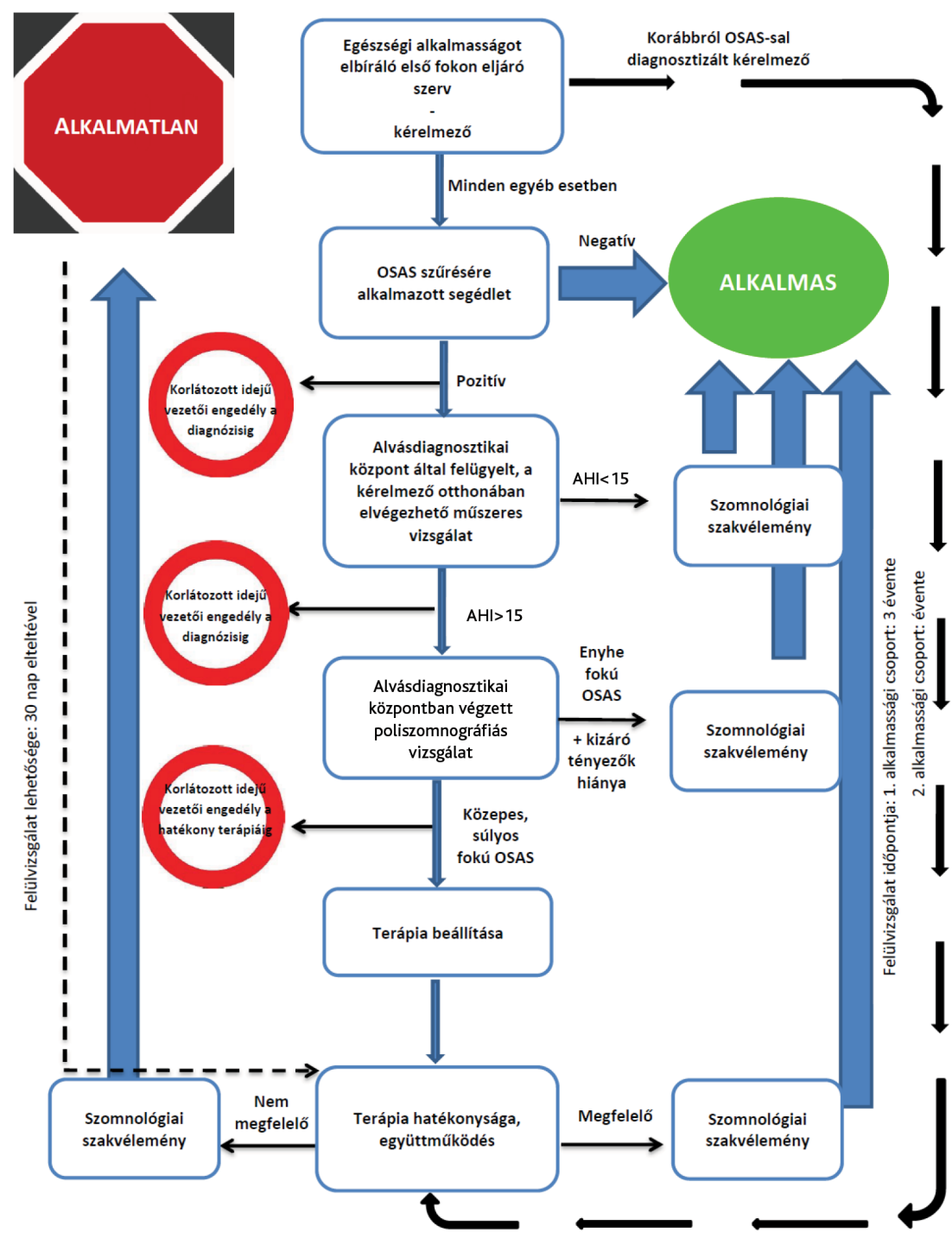

1. ábra | A közúti jármúvezetô egészségi alkalmasságának elbírálási algoritmusa obstruktív alvási apnoe szindróma vonatkozásában

felelő terápiás stratégia kialakítása az alvásdiagnosztikai központok (4. táblázat) feladata. A Magyar Alvásdiagnosztikai és Terápiás Társaság bízik benne, hogy szoros együttmúködéssel közösen megvalósítható a kitűzött cél.

Anyagi támogatás: A közlemény megírása, illetve a kapcsolódó kutatómunka anyagi támogatásban nem részesült.

Szerzői munkamegosztás: Sz. Z., T. P. kezdeményezte a cikk megírását, elvégezte az irodalomkutatást, megírta a magyar ajánlást. Á. Á. közremúködött az algoritmus kidolgozásában. A. J. K., Cs. D., K. L., L. A.: irodalomkutatást végzett, segített a gyakorlati részek kidolgozásában. A cikk végleges változatát valamennyi szerző elolvasta és jóváhagyta.

Érdekeltségek: A szerzőknek nincsenek érdekeltségeik.

\section{Irodalom}

[1] New Standards and Guidelines for Drivers with Obstructive Sleep Apnoea syndrome - Report of the Obstructive Sleep Apnoea Working Group. European Commission, DirectorateGeneral for Energy and Transport, Brussels, 2013. http://researchrepository.ucd.ie/bitstream/handle/10197/6809/ EU_sleep_apnoea.pdf?sequence $=1$

[2] Young, T., Palta, M., Dempsey, J., et al.: The occurrence of sleepdisordered breathing among middle-aged adults. N. Engl. J. Med., 1993, 328(17), 1230-1235.

[3] Edwards, B. A., O'Driscoll, D. M., Ali, A., et al.: Aging and sleep: physiology and pathophysiology. Semin. Respir. Crit. Care Med., 2010, 31(5), 618-633.

[4] Ancoli-Israel, S., Gehrman, P., Kripke, D. F., et al.: Long-term follow-up of sleep disordered breathing in older adults. Sleep Med., 2001, 2(6), 511-516.

[5] Banno, K., Walld, R., Kryger, M. H.: Increasing obesity trends in patients with sleep-disordered breathing referred to a sleep disorders center. J. Clin. Sleep Med., 2005, 1(4), 364-366.

[6] Ádám, Á.: ABPM in the screening of non-dipper hypertension and OSAS. Screening model in Primary Care. [ABPM a nondipper hypertonia és OSAS szűrésében. Szưrési modell az alapel- 
látásban.] Családorvosi Fórum, 2012, 12(1-2), 12-14. [Hungarian]

[7] Sforza, E., Janssens, J. P., Rochat, T., et al.: Determinants of altered quality of life in patients with sleep-related breathing disorders. Eur. Respir. J., 2003, 21(4), 682-687.

[8] Torzsa, P., Novák, M., Mucsi, I., et al.: The role of family physicians in the recognition and screening of obstructive sleep apnea. [A családorvos szerepe az obstruktív alvási apnoe szúrésében, felismerésében.] Orv. Hetil., 2008, 149(48), 2283-2290. [Hungarian]

[9] Hiestand, D. M., Britz, P., Goldman, M., et al.: Prevalence of symptoms and risk of sleep apnea in the US population: Results from the National Sleep Foundation Sleep in America 2005 poll. Chest, 2006, 130(3), 780-786.

[10] Young, T., Blustein, J., Finn, L., et al.: Sleep-disordered breathing and motor vehicle accidents in a population-based sample of employed adults. Sleep, 1997, 20(8), 608-613.

[11] Terán-Santos, J., Jiménez-Gómez, A., Cordero-Guevara, J.: The association between sleep apnea and the risk of traffic accidents. N. Engl. J. Med., 1999, 340(11), 847-851.

[12] Tregear, S., Reston, J., Schoelles, K., et al.: Obstructive sleep apnea and risk of motor vehicle crash: systematic review and metaanalysis. J. Clin. Sleep Med., 2009, 5(6), 573-581.
[13] Horstmann, S., Hess, C. W., Bassetti, C., et al.: Sleepiness-related accidents in sleep apnea patients. Sleep, 2000, 23(3), 383-389.

[14] Howard, M. E., Desai, A. V., Grunstein, R. R., et al.: Sleepiness, sleep-disordered breathing, and accident risk factors in commercial vehicle drivers. Am. J. Respir. Crit. Care Med., 2004, 170(9), 1014-1021.

[15] Leger, D.: The cost of sleep-related accidents: a report for the National Commission on Sleep Disorders Research. Sleep, 1994, $17(1), 84-93$.

[16] Pack, A. I., Pien, G. W.: How much do crashes related to obstructive sleep apnea cost? Sleep, 2004, 27(3), 369-370.

[17] Arbus, L., Tiberge, M., Serres, A., et al.: Drowsiness and traffic accidents. Importance of diagnosis. Neurophysiol. Clin., 1991, 21(1), 39-43.

[18] Johns, M. W.: A new method for measuring daytime sleepiness: the Epworth sleepiness scale. Sleep, 1991, 14(6), 540-545.

(Torzsa Péter dr., Budapest, Kútvölgyi út 4., 1125 e-mail: torzsa.peter@med.semmelweis-univ.hu)

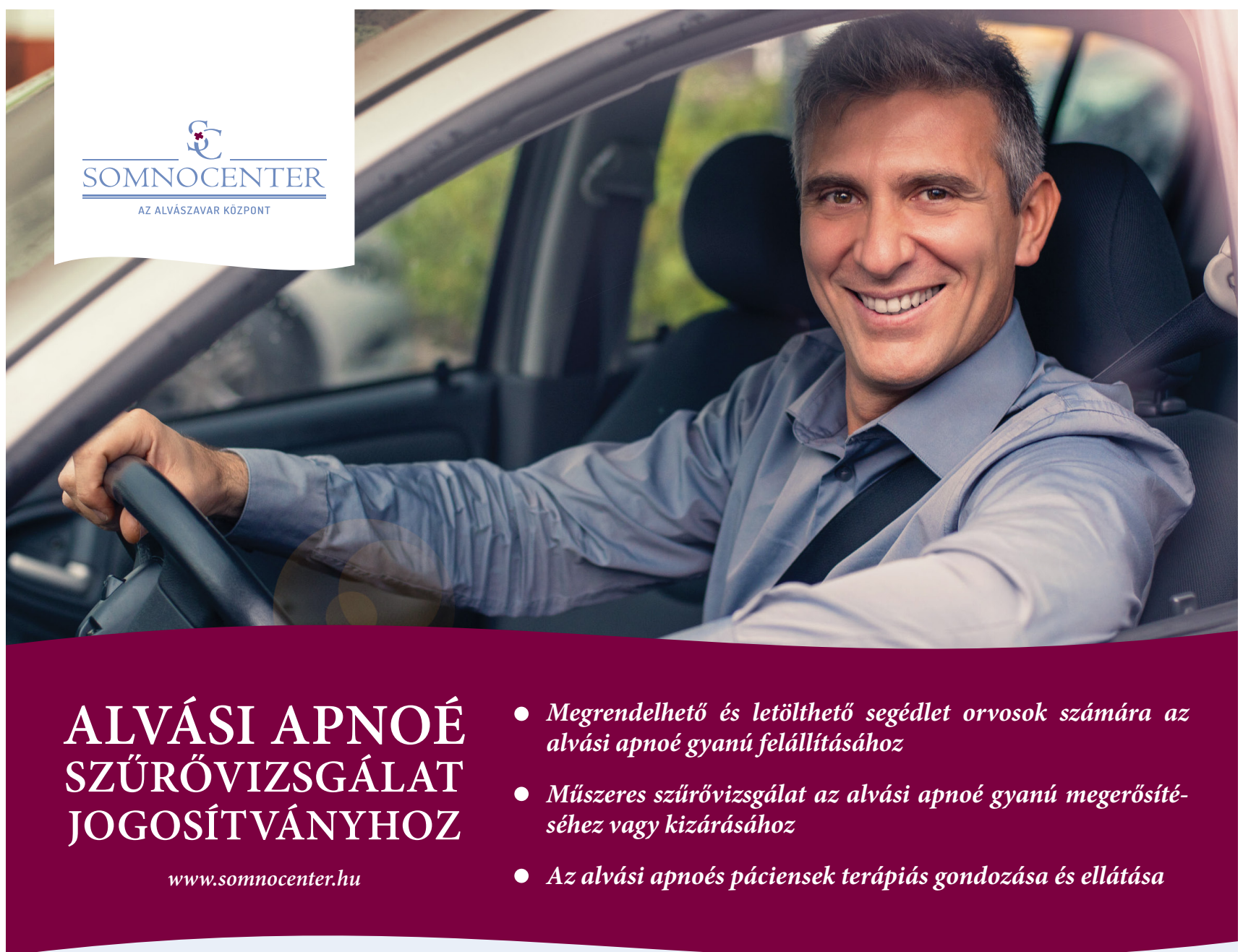

BUDAPEST +36205078222 